\title{
Perceptions about Self-recording Videos to Develop EFL Speaking Skills in Two Ecuadorian Universities
}

\author{
Maria Asuncion Rojas Encalada \\ Universidad Técnica de Machala, Machala, Ecuador \\ Sonia Magali Arteaga Sarmiento \\ Universidad de Azuay, Cuenca, Ecuador
}

\begin{abstract}
The present study explores the perceptions of EFL students from two Ecuadorian universities on the use of Self-Recording Videos (SRV) to develop speaking skills. As students do not have the opportunity to talk in the target language outside their classes, the authors of the present study analyzed the participants' viewpoints regarding SRV to improve their conversational abilities. There is still limited research on the use of SRV for English speaking practice in a foreign country, so the researchers' purpose is to fill this gap in the literature to contribute to further studies on the topic. The authors consider essential to acknowledge the positive aspects of using this technique from the learners' perspectives. For this purpose, participants were required to self-record a video related to the content of the class during the week and submit it to the Moodle platform.
\end{abstract}

Index Terms - self-recorded videos, perceptions, speaking skills, video-based learning, mobile devices, digital story telling

\section{INTRODUCTION}

We live in the age of moving images. The internet, the various practices to capture images, the emergence of distribution channels like YouTube are changing the way students learn and the way teachers teach, specifically a foreign language. This paper focuses on the learners' perceptions about the use of SRV to enhance speaking abilities in two Ecuadorian universities.

Currently, there is not enough research on the use of SRV to develop this skill in a non-English speaking country. Therefore, the authors consider essential to recognize the participants' opinions to contribute to the scientific community for future research on this topic.

The present study was conducted in two Ecuadorian universities. One was public, and the other one was private, located on the coast and highland regions of Ecuador. There were 81 participants (17 males and 64 females) from the two universities who volunteered to be part of this research.

To collect the data, the researchers applied an Electronic Survey to identify the students' perspectives on the use of SRV to develop speaking skills. The survey consisted of 5 Multiple Choice questions, Closed-ended questions, and two open-ended questions. The survey was applied through a Google Apps Form.

The purpose of this study was to identify the opinion students had when they self-recorded videos as a way to enhance their verbal skill. The researchers aimed at investigating how participants felt and what recommendations they would give to improve the application of this technique in future classes or in the worst case to stop using this strategy.

The paper is structured in 5 sections. The first section, the literature review evokes the most prominent studies related to video-based learning. The second section is related to the methodology of the research. In this section, the researchers explain the participants' background, the instrument used and how it was structured. The third section shows the results participants gave to the questionnaire. The fourth section presents the conclusions reached with the investigation and offers space for other possible research in the same field. Finally, the last section indicates the bibliography used in the present study.

\section{LITERATURE REVIEW}

\section{A. Underpinning Theories}

Constructivist learning emphasizes the importance of learners in taking active roles when dealing with and understanding new information to construct their knowledge by linking prior knowledge and experiences (Nidzam, Ahmad, Chiao, Yahaya, Nizam, \& Abdullah, 2015). Similarly, Vygotsky (1978) stressed the importance of powerful experiences with people like classmates and teachers. He proposed that learning happens in three stages: the activities 
that the learner can carry out independently, the learning processes that cannot happen even with the help of others, and finally the learning that happens with the help of others. According to Vygotsky (1986), this zone, known as the zone of proximal development is enhanced through social interaction. Social interaction constitutes a fundamental role in the development of cognition. According to Chaiklin (2003), this social interaction or collaboration is used to assess the student's zone of proximal development to give the learner an opportunity to imitate and later on to help him in the maturation of his learning process for the future developments. Thus, the role of a teacher in a constructivist environment is of a guide and facilitator who provide students with opportunities of situations to construct knowledge in individual contexts and through social negotiation, collaboration, and experience (Murphy, 1997).

\section{B. Video-based Learning}

A research work conducted by Shih (2010) regarding video-based blogs aimed to create a blended teaching and learning model that combined online and face to face instructional blogging for an ESP course called English Public Speaking. The results of that study demonstrated that this technique would contribute to active learning and satisfied students if it is applied appropriately. The most remarkable aspects of this intervention were the peer and instructor's feedback and the blog features such as free access, revision simplicity, and motivating material for learning were main causes that boosted students' learning satisfaction.

Another study conducted by Yousef, Chatti \& Schroeder (2014) critically explores the contemporary investigation of Video-Based Learning (VBL) to comprehend the educational advantages and effectiveness of VBL for teachinglearning process profoundly. The results of the study demonstrated effective teaching methods, design, and reflection.

A different study related to VBL was conducted by Yu-Chih Sun \& Fang-Ying Yang (2013) in which the participants created two YouTube videos with informative presentations about the university campus in English to international students. The study combined service learning into an EFL speaking class using Web 2.0 tools as platforms and analyzed participants' viewpoints about the achievements in public speaking and language learning, their learning processes and strategies, the collaborative dialogs, and their perceptions regarding the Web 2.0 service learning involvements.

\section{Video Recording}

A similar study to the present one was conducted in an Ecuadorian public university by Soto, Espinosa, Vargas, Illescas, Fontaine-Ruiz, and Carrera (2017) who examined the perception of ESP students regarding the recording of videos to explain class content. Students were required to record one video per week for ten weeks of classes. The results demonstrated "that the technique improved participants' motivation and academic achievement. Furthermore, participants developed personal self-regulated strategies, self-awareness of their learning progress, and self-regulated environmental strategies, reporting a positive influence of the strategy for their language learning progress" (p. 385).

In this regard, students were encouraged to learn the language because of the linguistic enhancement. Similarly, they experience academic improvement since participants were required to be more committed to their learning process. As a consequence, students applied self-regulatory strategies to develop their cognitive abilities. Socially, students develop communicational skills with their peers when seeking the help of more knowledgeable classmates (Soto et al., 2017). For this reason, "explaining content through videos has a positive impact on language learning in a variety of aspects, becoming a powerful tool for EFL/ESP classes. It encourages learners to take ownership of their learning process and induces them to become autonomous" (p. 390).

Another study related to video recording to develop speaking skills and conducted by Kirkgoz (2011), investigated the outcomes of a Task-Based Learning blended course. The results demonstrated that participants made significant development in their speaking skills, and were motivated by the use of technology in the classes. Additionally, the outcomes revealed that the use of video camera had a positive influence on students' self-assessment of the speaking tasks.

\section{Mobile Devices}

According to Ahn \& Lee (2016), speaking is the most complicated language ability for English as foreign language (EFL) learners, and the EFL classroom is incapable of offering sufficient opportunities for speaking practice. Therefore, mobile devices provide new opportunities for language learning, but they have some limitations, mainly concerning learning to speak. Automatic speech recognition (ASR) boosts student speaking and pronunciation. Mobile-assisted language learning (MALL) has been investigated, and the learning results of speaking through the use of mobile technologies have not frequently been reported.

Another study showed how learners' speaking and listening skills practices using mobile devices had different connections depending on their levels of proficiency. The study pointed out that in the future students would continue using mobile devices to explore and interact with surrounding authentic contexts. In other words, students will be able to practice listening and speaking skills with content connected to their daily life (Hwang, Huang, Shadiev, Wu \& Chen, 2014).

Likewise, a study related to learning through mobile devices was conducted by Hwang, Huang, Shadiev, Wu \& Chen (2014) that aimed to investigate learners' insights and purposes concerning learning activities reinforced by mobile 
technology. It also examines the relationship between different kinds of EFL speaking and listening practice using mobile technology and learning achievement, which was not reported in previous studies.

\section{E. Digital Storytelling}

Various researchers such as Razmi, Pouralib \& Nozad (2014); Hwang, Shadiev., Hsu, Huang, Hsu, \& Lin (2014); and Pardo (2014) have conducted studies on the use of Digital Storytelling (DST) to develop speaking skills through innovative materials. In this respect, these authors' findings point out that DST increases students' motivation to learn by organizing ideas and expressing thoughts meaningfully using technological tools that include computer-based tools, web-based multimedia system, and animations. However, in Pardo's study, respondents mentioned oral components to be the biggest challenge, specifically pronunciation.

\section{METHOdOLOGY AND InSTRUMENTS}

\section{A. Sample}

The participants in our research were students from a public and a private university. One of the groups of participants was majoring in Hotel and Tourism Management. Their age ranged between 18 and 22. The students in the private university were majoring in Clinic Psychology and Basic Education. Their ages varied from 18 to 22 . They take English as a Foreign Language classes as part of their curriculum.

Students participating in this research were asked to use presentations aids such as PowerPoint, wall chart papers or just role play to record a video. They were not allowed to read from the presentation aids. Therefore, they needed to rehearse their scripts before self-recording the videos and to redo it as many times as necessary, as long as they submit it in the due date.

The present study is action research that applies qualitative methods of research and a literature review to determine the following two aspects:

1. The participants' viewpoints about the use of SRV to develop their speaking skills

2. The different ways of SRV to develop speaking skills.

The sample consisted of 81 participants who volunteered to take part in this research work (17 males and 64 females). To participate in the study learners had to be officially registered as a student in each of the participants' universities during the period 2017-2018, to be present regularly in class, and to be willing to participate in the research.

TABLE 1

\begin{tabular}{|l|l|l|l|}
\hline \multicolumn{5}{|c|}{ PARTICIPANTS } \\
\hline Universities & Male & Female & Total \\
\hline Public & 12 & 25 & 37 \\
\hline Trivate & 5 & 39 & 44 \\
\hline
\end{tabular}

\section{B. Instruments}

Electronic Survey was used to identify learners' perceptions of the use of SRV to develop speaking skills. The researchers designed this instrument ad hoc. The survey included 5 Multiple Choice, Closed-ended questions, and two open-ended questions. The questions were formulated to learn about the students' perceptions of the use of SRV. Professors from both the public and private university examined the instruments. Therefore, both universities used the Expert-Review Triangulation Method and piloted the survey with a group of students different from the intervention group. The survey was applied through a Google Apps Form.

To analyze the results, the researchers used both: a descriptive statistical analysis of the Likert scale questions, and the discourse analysis to interpret the responses participants gave in the open-ended questions of the questionnaire.

\section{RESULTS}

The survey in the two universities was carried out during the second semester of the year 2017, in February. The following tables show the results: 
TABLE 2

PERCEPTION OF THE STUDENTS FROM THE TWO UNIVERSITIES ABOUT THE USE OF SRV TO DEVELOP SPEAKING SKILLS (MULTIPLE CHOICE CLOSEDENDED QUESTIONS)

\begin{tabular}{|c|c|c|c|c|c|c|c|c|c|c|}
\hline \multirow[b]{2}{*}{ ITEMS } & \multicolumn{2}{|c|}{ Strongly Agree } & \multicolumn{2}{|c|}{ Agree } & \multicolumn{2}{|c|}{$\begin{array}{l}\text { I do not } \\
\text { know }\end{array}$} & \multicolumn{2}{|c|}{ Disagree } & \multicolumn{2}{|c|}{$\begin{array}{l}\text { Strongly } \\
\text { disagree }\end{array}$} \\
\hline & $\mathrm{n}$ & $\%$ & $\mathrm{~N}$ & $\%$ & $\mathrm{n}$ & $\%$ & $\mathrm{~N}$ & $\%$ & $\mathrm{n}$ & $\%$ \\
\hline $\begin{array}{l}\text { SRVs have helped me to develop my speaking } \\
\text { abilities. }\end{array}$ & 39 & 48.1 & 35 & 43.2 & 2 & 2.5 & 1 & 1.2 & 4 & 5 \\
\hline I consider difficult to speak in the SRV. & 12 & 14.8 & 28 & 34.6 & 11 & 13.6 & 23 & 28.4 & 7 & 8.6 \\
\hline I feel motivated when speaking in the SRV. & 27 & 33.3 & 35 & 43.2 & 8 & 9.9 & 8 & 9.9 & 3 & 3.7 \\
\hline $\begin{array}{l}\text { Speaking in the SRV helps me to function well } \\
\text { when I become a professional. }\end{array}$ & 41 & 50.61 & 25 & 30.9 & 10 & 12.3 & 2 & 2.5 & 3 & 3.7 \\
\hline $\begin{array}{l}\text { The SRVs are an excellent option to practice } \\
\text { English speaking skills }\end{array}$ & 46 & 56.8 & 24 & 29.6 & 5 & 6.2 & 2 & 2.5 & 4 & 5 \\
\hline
\end{tabular}

- The questions were carried out in Spanish to avoid misunderstandings. They were translated for this paper.

The analysis of the data obtained from the students' answers resulted in three categories: positive aspects with five codes, aspects that need to be improved with five codes as well and no need for improvement with one code.

TABLE 3

PERCEPTION OF THE STUDENTS FROM THE TWO UNIVERSITIES ABOUT THE USE OF SRV TO DEVELOP SPEAKING SKILLS (OPEN-ENDED QUESTIONS)

\begin{tabular}{|c|c|c|c|}
\hline Categories & 1. Positive aspects & $\begin{array}{l}\text { 2. Aspects that need to be } \\
\text { improved }\end{array}$ & 3. No need for improvement \\
\hline \multirow[t]{5}{*}{ Codes } & Pronunciation development & Teach more vocabulary & No suggestions \\
\hline & Real practice & Teach more pronunciation & \\
\hline & Improvisation & Editing videos & \\
\hline & Learning improvement & $\begin{array}{l}\text { Allow more time to prepare the } \\
\text { videos. }\end{array}$ & \\
\hline & Fear decrease & Immediate teacher correction & \\
\hline
\end{tabular}

After analyzing the open-ended questions in the survey, the opinion of the students reveals that the uses of SRVs in the class have a very positive effect on English learning. Figure 1 shows the number of times students mentioned the positive and need to be improved aspects.

TABLE 4

\begin{tabular}{llllll}
\hline Positive aspects & $\begin{array}{l}\text { Number of times it } \\
\text { was mentioned }\end{array}$ & $\begin{array}{l}\text { Aspects that need } \\
\text { to be improved }\end{array}$ & $\begin{array}{l}\text { Number of times it } \\
\text { was mentioned }\end{array}$ & $\begin{array}{l}\text { No need for } \\
\text { improvement }\end{array}$ & $\begin{array}{l}\text { Number of times it } \\
\text { was mentioned }\end{array}$ \\
\hline $\begin{array}{l}\text { Pronunciation } \\
\text { development }\end{array}$ & 20 & $\begin{array}{l}\text { Teach more } \\
\text { vocabulary }\end{array}$ & 3 & No suggestions & 14 \\
Real practice & 6 & $\begin{array}{l}\text { Teach more } \\
\text { pronunciation }\end{array}$ & 7 & \\
Improvisation & 3 & Editing videos & 3 & \\
$\begin{array}{l}\text { Learning } \\
\text { improvement }\end{array}$ & 8 & $\begin{array}{l}\text { Allow more time to } \\
\text { prepare the videos }\end{array}$ & 9 & \\
Fear decrease & 3 & Immediate teacher & 3 & \\
correction & & 25 & 16 \\
TOTAL & 40 & & &
\end{tabular}




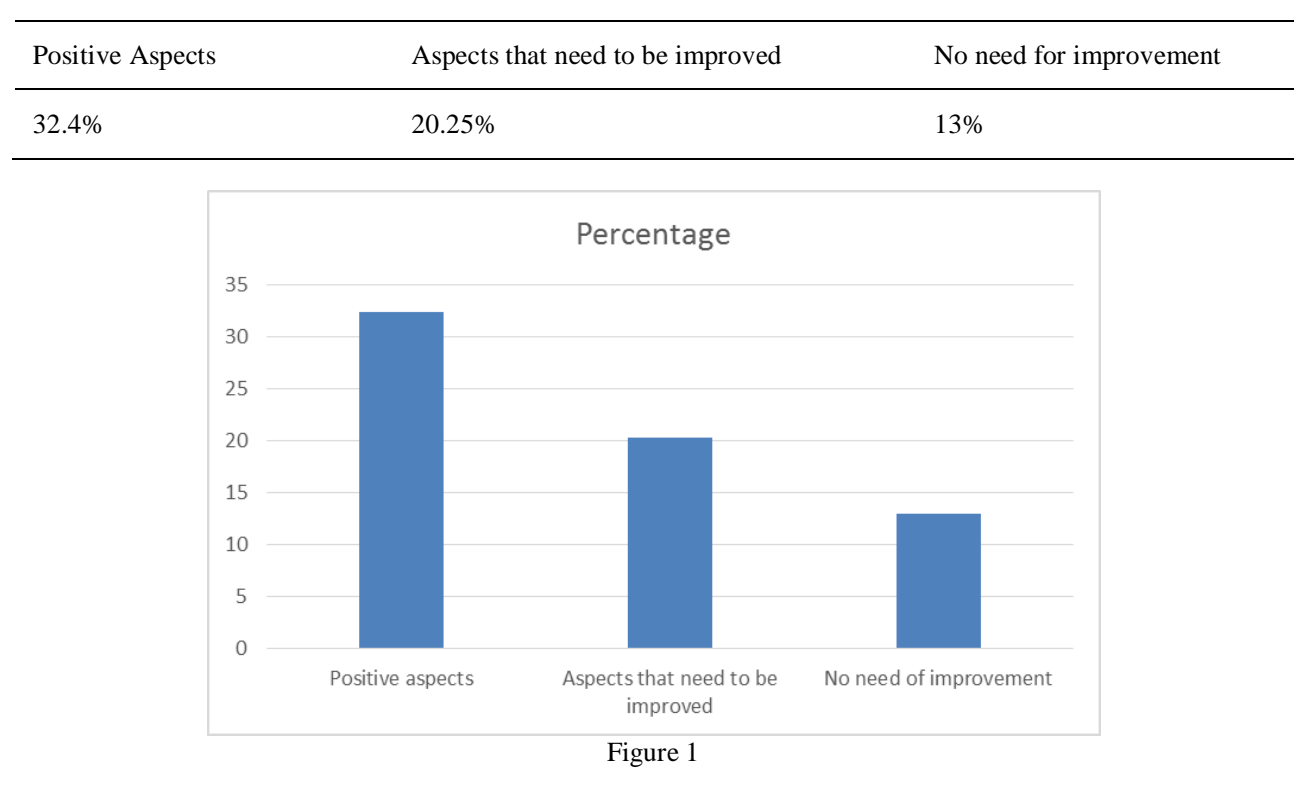

\section{DISCUSSION AND CONCLUSION}

According to the results obtained from the multiple choices close-ended questions (Table 2) applied to 81 participants from the two Ecuadorian universities, we observe the following outcomes:

For the first item which corresponds to the statement "SRVs have helped me to develop my speaking abilities," we find out that the majority of students, $48,1 \%$ of them, very agreed and that $43,2 \%$ of them agreed. In this respect, Yousef., Chatti \& Schroeder (2014) maintain that students consider VBL much more gratifying than classes that use traditional methods of teaching. Whereas, $1,2 \%$ disagreed, 2,5\% do not know, and 5\% disagreed which implies that only a small percentage of students are not satisfied with this technique. It could be concluded, then, that this generation of students prefer working with current digital tools and all the instruments that they offer. Accordingly, Kirkgoz (2011), demonstrated that through the use of video recording participants improved their speaking skills significantly, and were encouraged by the use of technology in the classes.

About the second item, "I consider difficult to speak in the SRVs," most of the participants, 34,6\% of them, agreed and only 14, 8\% very agreed with the statement. A study conducted by Ahn \& Lee (2016), associated with this result, maintain that speaking is the most challenging language skill for EFL learners and EFL instructors do not offer plentiful opportunities for speaking practice, consequently, speaking practice through technological resources become a problematic activity for learners. On the other hand, $28.4 \%$ disagreed and 8,6\% very disagree. Considering this, the study conducted by Yu-Chih Sun \& Fang-Ying Yang (2013) on VBL in which the participants created YouTube informative presentations videos, indicate that the benefits of practicing speaking through SRV increase their confidence in English speaking, It is also observed that 13,6 of respondents do not know.

According to the third item, "I am motivated when I am speaking in the SRVs," $43,2 \%$ of participants agreed with this statement. In this respect, several studies, such as Pardo (2014), Yousef, Chatti \& Schroeder (2014), Razmi, Pourali \& Nozad (2014), Hwang, Shadie, Hsu, Huang, Hsu, \& Lin (2014) supported activities with technological assistance to boost students' motivation to speak in English. While on the contrary, 33, $3 \%$ disagreed, 3, $7 \%$ very disagree, 9, $9 \%$ disagree and $9 \%$ do not know. Several students are not well motivated when participating in this activity because some classes do not offer enough activities with technological assistance to practice English speaking. In this regard, the study conducted by Shih (2010) that mixed online and face to face instructional blogging, indicated that this technique contributed to having satisfied students.

The fourth item, "speaking in the videos help me for my professional future," 50,61\% very agreed and 30, $9 \%$ agreed. The practice of speaking skills through the use of SRV is a significant pedagogical technique in ESP courses since the teacher, in this constructivist environment, becomes a facilitator who provides students with real situations in which they are allowed to socialize and collaborate with each other to build new knowledge (Murphy, 1997). This practice through recording their speaking in the videos will enable them to develop their speaking skills and function appropriately in their future professions. Furthermore, another study conducted by Hwuang, Huang, Shadiev, Wu \& Chen (2014) about the use of mobile phones to develop speaking skills maintain that learners will be enabled to practice speaking skills in contexts that resemble real-life situations. In this regard, technologically assisted classes, such as the ones that use SRVs or mobile phones, have proved to be very useful to enable students to speak in real-life situations. On the contrary, only $2.5 \%$ of respondents disagree, $3.7 \%$ very disagree, and $12.3 \%$ do not know which demonstrate that a small portion of participants does not support the use of SRV as a technique to function appropriately in their professional future. 
Finally, the fifth item that corresponds to the statement "SRVs are a good option to practice the English speaking ability," 56, 8 of the participant very agreed and 29, $6 \%$ agreed. In this respect studies conducted by various authors such as Shih (2010), Yousef, Chatti \& Schroeder (2014), Yu-Chih Sun \& Fang-Ying Yang (2013) consider VBL environments useful for the development of learners' speaking skills. On the contrary, $2.5 \%$ disagree, $5 \%$ very disagree and $6.2 \%$ do not know which demonstrate that only the minority of participants do not acknowledge SRVs as an excellent option to improve their speaking.

Table 3 shows that, when referring to the use of SRV, students mentioned more positive aspects than aspects requiring improvement. A high percentage of answers demonstrated that students have no suggestions regarding the use of this type of videos. These results support the findings in the Likert scale part of the questionnaire. Among their answers, some students mention, "no suggestions; everything is perfect." Some other students wrote as their answers "It is very appropriate, so I would not change anything," which shows that students were glad to use the videos as part of their learning process.

Among the positive aspects, students mentioned that they had improved their vocabulary and pronunciation development. Typical responses were: "I learn new words," "I improve pronunciation." A high number of participants considered that SRVs provide opportunities to practice what they have learned in class because they can express themselves naturally. The common responses were: "I learn to express myself effectively" or "I apply what I have learned in class." In this regard, Soto et al. (2017) mention that students are encouraged to learn the target language through video recording because of the linguistic improvement.

Additionally, a significant number of answers mentioned feeling motivated when preparing the SRVs since they are allowed to improvise. Some of the answers coincide in saying "I can improvise and I like it." Respectively, Soto et al. (2017) consider that the technique increases participants' motivation and educational success. Another positive aspect mentioned is the fact that they feel less fear to speak English. An example of this type of response is: "I can speak with other people feeling no fear." In this respect, some studies such as Yu-Chih Sun \& Fang-Ying Yang (2013) and Ahn \& Lee (2016) mentioned that creating videos in YouTube increase students' self-confidence when speaking English.

Learners mentioned teachers' help to improve vocabulary and pronunciation. Among the aspects that need to be improved, some participants expressed that instructors need to teach more vocabulary so that they can express more efficiently in the videos. For instance, "the teacher should give us an extra class to explain those words that are difficult to pronounce." Two participants mentioned that instructors need to teach not only vocabulary but also the pronunciation of new words. Their answers, in general, suggested "more help with the pronunciation." In this regard, Ahn and Lee (2016) support the use of ASR to enhance student speaking and pronunciation.

Edition and time to improve their performance in the videos were other factors mentioned by participants in the study. Some students mentioned that the use of SRV could be improved by allowing them to edit their videos. Additionally, other students asked for more time when working on them to edit the videos.

Teacher's assistance was another aspect noticed by students to improve their speaking skills. Some participants expressed the need for faster feedback from the teacher to correct pronunciation mistakes. A typical answer says the following: "To show the videos in class so that the teacher corrects pronunciation mistakes." Correspondingly, Murphy (1997) maintain that the teacher in a constructivist environment function as a guide and facilitator who provides students opportunities to construct knowledge socially, collaboratively, and experientially.

It is essential to emphasize that a significant number of students do not give suggestions to improve the use of SRV. Instead, they encourage the use of such videos not only in class but as homework: "More homework with videos."

The findings of the study reveal that students have a robust and decisive point of view about the use of SRV, which coincides with Shih`s research in 2010 in the fact that blended teaching contributes to productive learning and satisfaction of students. Table 2 shows that students find SRV motivating to learn English. Yousef., Chatti \& Schroeder (2014) claim that the rate of interaction and learner satisfaction is higher than in the traditional classroom. This fact concurs with the findings of the present study. A high percentage of participants do not recommend changes in the features of the SRVs.

One of the most positive aspects of using SRV, according to the participants` responses, is the feeling they have about improving pronunciation and how it has helped them to become less fearful when speaking in English. As YuChih Sun \& Fang-Ying Yang (2013) and Ahn \& Lee (2016) mentioned, creating videos in YouTube does improve pronunciation; thus, students increase their confidence in speaking English.

Additionally, while participants expressed that they had learned vocabulary and pronunciation, they still needed the help of the teacher to improve pronunciation. This fact is manifested in Pardo (2014), who expressed that although the results of his research were very confident in developing speaking skills, participants still had some pronunciation problems.

Although the research reached its objectives in trying to find out the participants perceptions, some limitations and shortcomings have to be explained. One of them is about the instrumentation. Since the survey was online, the lack of a trained interviewer to clarify questions could have possibly led to less reliable information.

Second, although the purpose of the study was to identify the students` perceptions about using SRVs as a tool to improve speaking skills, the results cannot be very generalizable as the sample is small. Nevertheless, the researchers considered this tool the best way to interview due to the number of students. 
Even though the questionnaire measured the students`attitude towards the use of SRV, it did not intend to provide evidence of the students' actual behavior about communication skills in the vocal performance.

Also, the results from the public and private universities are similar. However, as one is public and the other private, this opens space for further investigation that could reveal perceptions of differences between private and public universities.

\section{ACKNOWLEDGMENTS}

The authors wish to thank the authorities of Universidad Técnica de Machala and Universidad del Azuay for supporting the present research. They also like to show their gratitude to their colleagues who provided insight and expertise that greatly assisted the study.

\section{REFERENCES}

[1] Ahn, T. \& Lee, S. (2016). The user experience of a mobile speaking application with automatic speech recognition for EFL learning. British Journal of Educational Technology 47.4, 778-786.

[2] Chaiklin, S. (2003). The zone of proximal development in Vygotsky's analysis of learning and instruction. In A. Kozulin, B. Gindis, V. Ageyev \& S. Miller (Eds.), Vygotsky education theory in cultural context. Cambridge, UK: Cambridge University Press, 39-63.

[3] Hwang, W-Y., Huang, Y-M., Shadiev, R., Wu, S-Y., \& Chen, S-L. (2014). Effects of using mobile devices on English listening diversity and speaking for EFL elementary students. Australasian Journal of Educational Technology 30.5, 503-516.

[4] Hwang, W., Shadiev, R., Hsu, J., Huang, Y., Hsu, G., \& Lin, Y. (2014). Effects of storytelling to facilitate EFL speaking using Web-based multimedia system. Computer Assisted Language Learning 29.2, 215-241.

[5] Kirkgoz, Y. (2011). A Blended Learning Study on Implementing Video Recorded Speaking Tasks in Task-Based Classroom Instruction. The Turkish Online Journal of Educational Technology 10.4, 1-13.

[6] Murphy, E. (1997). Constructivism: From philosophy to practice. Lanham, Maryland: ERIC.

[7] Nidzam, C., Ahmad, C., Chiao, W., Yahaya, A., Nizam, M. \& Abdullah, M.F.L. (2015). Relationship between constructivist learning environments and educational facility in science classrooms. Procedia-Social and Behavioral Science, 1991(2015), 1952-1957.

[8] Pardo, B.S. (2014). Digital Storytelling: A Case Study of the Creation, and Narration of a Story by EFL Learners. Digital Education 26, 74-84.

[9] Razmi, M., Pourali, S. \& Nozad, S. (2014). Digital Storytelling in EFL Classroom (Oral Presentation of the Story): A Pathway to Improve Oral Production. Procedia - Social and Behavioral Sciences 98 (2014), 1541 - 1544.

[10] Shih, R. (2010). Blended learning using video-based blogs: Public speaking for English as a second language students. Australasian Journal of Educational Technology 26.6, 883-897.

[11] Soto, S. T.; Espinosa, L.F.; Vargas Caicedo, E; Illescas; Fontaines-Ruiz, T.; Carrera, D. (2017). How Does Explaining Content Through Videos Benefit Language Learners? Esp Students Tell us About it. Turkish Online Journal of Educational Technology. Special Issue for IETC 2017. 385-391

[12] Vygotsky, L. S. (1978). Mind in society: the development of higher psychological processes. Cambridge, MA: Harvard University Press

[13] Vygotsky, L. S. (1986). Thought and language. Boston, MA: MIT Press

[14] Yousef, A., Chatti, M., Schroeder, V. (2014). Video-Based Learning: A Critical Analysis of The Research Published in 20032013 and Future Visions. Paper presented at the Sixth International Conference on Mobile, Hybrid, and Online Learning, Barcelona, Spain.

[15] Yu-Chih Sun \& Fang-Ying Yang. (2013). I help, therefore, I learn: service learning on Web 2.0 in an EFL speaking class, Computer Assisted Language Learning 28.3, 202-219.

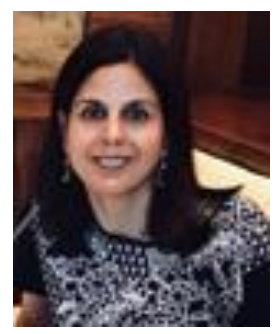

Maria A. Rojas is an Ecuadorian professor and researcher. In the year 2017, she earned a Master's Degree in Teaching English as a Foreign Language at Escuela Superior Politécnica del Litoral (ESPOL) in Ecuador. Her primary field of study focuses on English Language Teaching (ELT). She has been working as an ESP professor at Universidad Tecnica de Machala (UTMACH) in Machala, Ecuador since the year 2014.

Prof. Rojas is a member of a Research Group called ELT Innovator at UTMACH. Some of her recent publications are The Influence of Implementing Role-play as an Educational Technique on EFL Speaking Development (Theory and Practice in Language Studies, 2018). Collaborative Work and Technological Means for improving Learners' English Language Writing Production (Turkish Online Journal of Educational Technology, 2017), Performance-Based Tasks as a Mean to Assess the Speaking of Learners of English as a Foreign Language (Turkish Online Journal of Educational Technology, 2017), and English Language Teaching Approaches: A comparison of the Grammar-Translation, Audio-lingual, Communicative, and Natural Approaches (Theory and Practice in Language Studies, 2017).

In June she was awarded recognition from Universidad Tecnica de Machala due to her scientific production. She has also recently acquired her Certificate in Advanced English according to The Common European Framework of Reference for Languages Level C1. 


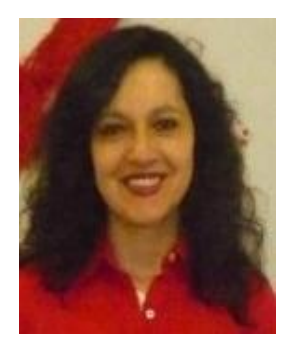

Sonia M. Arteaga was born in Ecuador on December $14^{\text {th }}, 1973$. She is an English teacher from Ecuador. Her research interest is metacognitive reading strategies, blended classrooms and English language teaching. She has an MA in TEFL ate ESPOL (Guayaquil-Ecuador) and is a frequent speaker at ELT events both in Ecuador and in the rest of Latin America as well as Inted and Aiated. She is currently pursuing her doctoral program in Arts and Education at University of Rosario-Argentna

She is currently the head of the English Unit of University of Azuay. She has publications in the following fields: The effects of metacognitive strategy instruction on intermediate learners' reading comprehension skills (Hexágono Pedagógico). Virtual learning environment: effect of blended classrooms on the listening skill in a1 students (Edulite). Emotional and Motivational Problems in Spanish- Speaking Adolescents with Reading Disabilities (Acta Psychopathologica). Critical thinking in an increasing digital world (Fenopina). Book reviews and webinar reviews at El Gazzette. She is a member of TESOl and AITEFL. 